\title{
Persulfate oxidation of MTBE- and chloroform-spent granular activated carbon ${ }^{\text {is }}$
}

\author{
Scott G. Huling a,*, Saebom Ko ${ }^{\mathrm{b}, 1}$, Saehan Park ${ }^{\mathrm{c}, 2}$, Eunsung Kan ${ }^{\mathrm{d}, 3}$ \\ a U.S. Environmental Protection Agency, Office of Research and Development, National Risk Management Research Laboratory, Robert S. Kerr Environmental Research Center, \\ P.O. Box 1198, Ada, OK 74820, United States \\ ${ }^{\mathrm{b}}$ National Research Council, Robert S. Kerr Environmental Research Center, P.O. Box 1198, Ada, OK 74820, United States \\ c Department of Chemistry and Biochemistry, University of Arizona, P.O. Box 210041, Tucson, AZ 85721, United States \\ d Center for Biofilm Engineering, Montana State University, Bozeman, MT 59715, United States
}

\section{A R T I C L E I N F O}

\section{Article history:}

Received 24 March 2011

Received in revised form 27 May 2011

Accepted 25 June 2011

Available online 1 July 2011

\section{Keywords:}

Persulfate

Thermal

Oxidation

MTBE

Activated carbon

\begin{abstract}
A B S T R A C T
Activated persulfate $\left(\mathrm{Na}_{2} \mathrm{~S}_{2} \mathrm{O}_{8}\right)$ regeneration of methyl tert-butyl ether (MTBE) and chloroform-spent GAC was evaluated in this study. Thermal-activation of persulfate was effective and resulted in greater MTBE removal than either alkaline-activation or $\mathrm{H}_{2} \mathrm{O}_{2}$-persulfate binary mixtures. $\mathrm{H}_{2} \mathrm{O}_{2}$ may serve multiple roles in oxidation mechanisms including Fenton-driven oxidation, and indirect activation of persulfate through thermal or ferrous iron activation mechanisms. More frequent, lower volume applications of persulfate solution (i.e., the persulfate loading rate), higher solid/solution ratio ( $\left(\mathrm{GAC} \mathrm{mL}^{-1}\right.$ solution), and higher persulfate concentration (mass loading) resulted in greater MTBE oxidation and removal. Chloroform oxidation was more effective in URV GAC compared to F400 GAC. This study provides baseline conditions that can be used to optimize pilot-scale persulfate-driven regeneration of contaminant-spent GAC.
\end{abstract}

Published by Elsevier B.V.

\section{Introduction}

\subsection{MTBE}

Methyl tert-butyl ether (MTBE), a widely used gasoline additive, is found in numerous groundwater and surface water reservoirs across the U.S. [1]. MTBE is mobile and persistent in the environment due to its high aqueous solubility $\left(51.0 \mathrm{~g} \mathrm{~L}^{-1}, 25^{\circ} \mathrm{C}\right)$, low Henry's constant, and biorecalcitrance. These properties contribute to the difficulty and expense in treating MTBE-contaminated water. The US EPA advisory for MTBE in drinking water to control levels that prevent adverse taste and odor (i.e., 20-40 $\mu \mathrm{g} \mathrm{L}^{-1}$ ) [2]. MTBE concentrations in ground water near the point of origin (i.e., source area) may be orders of magnitude higher due to the high aqueous solubility of MTBE in water and the high MTBE content in spilled

\footnotetext{
is The U.S. Environmental Protection Agency, through its Office of Research and Development, funded and managed the research described here. It has not been subjected to Agency review and therefore does not necessarily reflect the views of the Agency, and no official endorsement should be inferred.

* Corresponding author. Tel.: +1 580436 8610; fax: +1 5804368614. E-mail addresses: huling.scott@epa.gov (S.G. Huling), ko.saebom@epa.gov

(S. Ko), saebal00@hotmail.com (S. Park), eunsung.kan@montana.edu (E. Kan).

1 Tel.: +1 5804368742 ; fax: +1 5804368614 .

2 Tel.: +1 4053802009 .

3 Tel.: +1 4065793370 .
}

gasoline. Treatment of MTBE-contaminated water is often achieved using granular activated carbon (GAC) adsorption.

\subsection{Chloroform}

Chlorination of source water is used to control microbial contaminants in drinking water. However, this treatment process may result in the formation of disinfection byproducts (DBPs) from the reaction between chlorine and natural organic matter. Trihalomethanes are one form of DBPs and includes chloroform. The US EPA regulates total trihalomethanes (i.e., chloroform, bromoform, bromodichloromethane, and dibromochloromethane) in drinking water and the maximum allowable annual average level is $80 \mathrm{ppb}$. Chloroform has the highest solubility in water of the four THMs, is usually present in the highest concentration, and is often removed by GAC.

\subsection{Granular activated carbon (GAC) regeneration}

GAC is one option used in water treatment to remove MTBE and other environmental contaminants. Once the GAC is saturated with the contaminant (i.e., "spent"), it is regenerated and placed back in service (i.e., reused), replaced with virgin GAC, or disposed as a solid waste. Chemical regeneration is an alternative to the conventional thermal regeneration process. The objectives of the treatment process are to transform adsorbed contaminants into less toxic byproducts, reestablish the sorptive capacity of the GAC 
for the target chemical(s), increase the useful life of the GAC, and reduce costs for GAC regeneration used in water and air treatment. Fenton-driven regeneration of GAC has been successfully demonstrated [3-6].

\subsection{Persulfate activation}

Sodium persulfate $\left(\mathrm{Na}_{2} \mathrm{~S}_{2} \mathrm{O}_{8}\right)$, another strong oxidant, can also be used to degrade a wide range of environmental contaminants and to regenerate GAC [7]. Activated persulfate reactions form sulfate radicals $\left(. \mathrm{SO}_{4}{ }^{-}\right)$which are a more powerful oxidant $(2.4 \mathrm{~V})$ than persulfate $(2.1 \mathrm{~V})$ [8] and provide a free radical reaction mechanism. Both thermal and chemical activation of persulfate can be used to form $\cdot \mathrm{SO}_{4}{ }^{-}$(R1)-(R3).

Thermal activation : $\mathrm{S}_{2} \mathrm{O}_{8}{ }^{2-} \stackrel{\text { heat }}{\longrightarrow} 2 \cdot \mathrm{SO}_{4-}$

Chemical activation : $\mathrm{S}_{2} \mathrm{O}_{8}{ }^{2-}+\mathrm{Fe}^{2+} \rightarrow \cdot \mathrm{SO}_{4}{ }^{-}+\mathrm{Fe}^{3+}+\mathrm{SO}_{4}{ }^{2-}$

Chemical oxidation : $\cdot \mathrm{SO}_{4}{ }^{-}+\mathrm{e}^{-} \rightarrow \mathrm{SO}_{4}{ }^{2-}$

Thermal activation $\left(30-70^{\circ} \mathrm{C}\right)$ of the persulfate anion $\left(\mathrm{S}_{2} \mathrm{O}_{8}{ }^{2-}\right)$ generates $\cdot \mathrm{SO}_{4}{ }^{-}$(R1) that may oxidize organic compounds [9-12]. For example, the MTBE reaction rate constant during persulfate oxidation increased with temperature $\left(1.3 \times 10^{-5} \mathrm{~s}^{-1}\left(20^{\circ} \mathrm{C}\right)\right.$, $5.8 \times 10^{-4} \mathrm{~s}^{-1}\left(50^{\circ} \mathrm{C}\right)$, and reaction intermediates, tert-butyl formate, tert-butyl alcohol (TBA), acetone, and methyl acetate, were also oxidized [9]. Similar observations have been reported regarding thermally activated persulfate and VOC oxidation $[10,12]$.

Reduced transition metals, including ferrous iron $\left(\mathrm{Fe}^{+2}\right)$ can activate persulfate ( $\mathrm{R} 2$ ) to form $\cdot \mathrm{SO}_{4}{ }^{-}$and effectively degrade dichlorophenol [13] and TCE in homogeneous systems [14] and GAC [7], and BTEX in soil [15]. Limited TCE oxidation was measured using unactivated persulfate, indicating the importance of persulfate activation. Unlike the Fenton mechanism, $\mathrm{Fe}^{2+}$ activation of persulfate does not involve a ferric iron $\left(\mathrm{Fe}^{3+}\right)$ reduction mechanism, and therefore, a continual source of $\mathrm{Fe}^{2+}$ is required. Under this condition, an excessive accumulation of iron may result [7] and would likely contribute to blockage of sorption sites and intraparticle MTBE and oxidant mass transport limitations [4].

The role of hydrogen peroxide $\left(\mathrm{H}_{2} \mathrm{O}_{2}\right)$ in a binary mixture of $\mathrm{H}_{2} \mathrm{O}_{2}$ and persulfate is poorly understood and not well documented. In one soil study, a $\mathrm{H}_{2} \mathrm{O}_{2}$-persulfate soil slurry resulted in greater contaminant oxidation [16]. However, due to the lack of appropriate controls (i.e., $\mathrm{H}_{2} \mathrm{O}_{2}$-only) and high concentrations of $\mathrm{Na}_{2} \mathrm{~S}_{2} \mathrm{O}_{8}\left(11.5 \mathrm{~g} \mathrm{~L}^{-1}\right)$ and $\mathrm{H}_{2} \mathrm{O}_{2}\left(59 \mathrm{~g} \mathrm{~L}^{-1}\right)$, it was not possible to assess whether $\mathrm{H}_{2} \mathrm{O}_{2}$ activated the persulfate or whether $\mathrm{H}_{2} \mathrm{O}_{2}$ was indirectly involved in other contaminant fate mechanisms. For example, possible roles of $\mathrm{H}_{2} \mathrm{O}_{2}$ include: (i) Fenton-driven oxidation of MTBE resulting from the reaction of $\mathrm{H}_{2} \mathrm{O}_{2}$ with background $\mathrm{Fe}$ in the soil and formation of $\mathrm{OH}$, (ii) exothermic $\mathrm{H}_{2} \mathrm{O}_{2}$ reactions followed by an increase in temperature and thermal-activation of persulfate, and (iii) Fenton-driven reduction of Fe(III) to Fe(II), and subsequent $\mathrm{Fe}(\mathrm{II})$-activation of persulfate.

Results from alkaline-activated persulfate studies are variable. Increased reductions in contaminant concentration were achieved in one study by increasing the mass of $\mathrm{KOH}$ [16]. Alkaline activation (pH 11-12) of persulfate using $\mathrm{NaOH}$ and oxidation of carbon tetrachloride in soil and groundwater showed better results than other activation methods [17]. Conversely, it was the least efficient activation method used to degrade BTEX in soil [15], and when used in conjunction with thermal activation $\left(40^{\circ} \mathrm{C}, \mathrm{pH} 10-12.5\right)$, a decline in the MTBE oxidation rate constant was measured [9]. A recommended guideline for alkaline-activation includes a $\mathrm{pH}$ range of 10.5-12 using $\mathrm{NaOH}$ amendment [18].

\subsection{Objectives}

The objectives of this study were to investigate process parameters that impact persulfate-driven oxidation of MTBE-spent GAC. These parameters include thermal- and alkaline-activation, and binary mixtures of $\mathrm{H}_{2} \mathrm{O}_{2}$ and persulfate, persulfate loading rate, persulfate concentration (i.e., mass loading), GAC type, and the solid/solution ratio. These process optimization results were subsequently used to assess the potential feasibility of regenerating chloroform (CF)-spent GAC.

\section{Methods and materials}

The GAC (URV, 8 × 30 mesh, Calgon Carbon Corp., Pittsburg, PA) was derived from bituminous coal and activated in a manner to minimize $\mathrm{H}_{2} \mathrm{O}_{2}$ reactivity [19]. The GAC was rinsed with de-ionized (DI) water, dried in an oven at $105^{\circ} \mathrm{C}$ and stored in a dessicator until used. The feasibility of regenerating chloroform (CF)-spent GAC was investigated using another type of GAC (F400, $8 \times 30$ mesh, Calgon Carbon Corp., Pittsburg, PA). The CF-spent GAC was produced at a water treatment facility where the post-GAC treated lake water contained small amounts of natural organic matter (NOM), forming CF upon chlorination (i.e., disinfection byproducts (DBPs)).

\subsection{MTBE and chloroform adsorption}

The MTBE adsorption step was performed by amending the MTBE solution $\left(0.12 \mathrm{~L}, 1.86-1.95 \mathrm{mg} \mathrm{L}^{-1}\right)$ to water-saturated GAC ( $5 \mathrm{~g} \mathrm{GAC}, 10 \mathrm{~mL}$ DI water) in $250 \mathrm{~mL}$ Erlenmeyer flasks wrapped in aluminum foil and parafilmed. The post-sorption MTBE solution was sampled in replicate after equilibrium $(>3 \mathrm{~d})$ and analyzed. Post-sorption MTBE concentrations ranged from 18 to $39 \mu \mathrm{g} \mathrm{L}^{-1}$ yielding approximately $44.9 \mathrm{mg}$ MTBE kg GAC ${ }^{-1}$. Differences between initial and final concentrations were used to determine the mass of MTBE adsorbed to the GAC. Approximately $20 \mathrm{~mL}$ of the remaining solution $(40 \mathrm{~mL})$ was decanted prior to the addition of the oxidant solution. Pre- and post-oxidation MTBE in GAC was measured by extracting GAC $(\sim 1 \mathrm{~g})$ in $10 \mathrm{~mL}$ of methanol $(\mathrm{MeOH})$ and analyzing the extract for MTBE.

The CF-spent F-400 GAC received in a sealed vessel from the water treatment plant was stored in a cold room $\left(5^{\circ} \mathrm{C}\right)$ until used. The wet GAC was homogenized in the cold room to minimize volatile losses, and transferred to $20 \mathrm{~mL}$ VOA vials. Test reactors were amended with DI water $(2 \mathrm{~mL})$ and immediately sealed with a two-way (mini-inert) valve cap which served as the test reactor. In addition to the $\mathrm{CF}$-spent GAC, $\mathrm{CF}$ was also amended to URV GAC to assess whether the type of GAC used in chemical regeneration affected $\mathrm{CF}$ oxidation in GAC. The CF stock solution $(40 \mathrm{~mL}$, $15 \mathrm{mg} \mathrm{L}^{-1}$ ) was added to VOA vials $(40 \mathrm{~mL})$ containing URV GAC $(1 \mathrm{~g})$. The post-sorption CF solution was sampled after equilibrium $(>3 \mathrm{~d}$ ) and analyzed. Differences between the initial and final CF concentrations were used to determine the mass of CF on the GAC. The CF-amended GAC ( $1 \mathrm{~g})$ was used in test reactors, amended with DI water $(2 \mathrm{~mL})$, and sealed with a two-way (mini-inert) valve cap which served as the test reactor.

\subsection{Reactor conditions}

\subsubsection{Temperature}

Separate reactors were used to assess the role of temperature $\left(25,35,45\right.$, and $\left.55^{\circ} \mathrm{C}\right)$ in thermal activation of persulfate and MTBE oxidation. Constant temperature was maintained in a temperaturecontrolled shaking water bath (Cole Parmer, Vernon Hills, IL). 


\subsubsection{Persulfate loading rate}

The same volume $(19.5 \mathrm{~mL})$ and concentration $\left(40 \mathrm{gL}^{-1}\right)$ of $\mathrm{Na}_{2} \mathrm{~S}_{2} \mathrm{O}_{8}$ solution was added to each reactor $\left(55^{\circ} \mathrm{C}\right)$ using two loading rates. The "high-loading rate" method involved the application of $6.5 \mathrm{~mL}$ of the persulfate solution per day for 3 sequential days (19.5 $\mathrm{mL}$ total volume, $40 \mathrm{~g} \mathrm{~L}^{-1}$ ), and the "light-loading rate" involved the same volume and concentration, but at higher application frequency and lower volume $(0.5 \mathrm{~mL} / 5 \mathrm{~min})$. The light-loading rate was used in experiments involving CF-spent, F400 GAC, and CF-amended, URV GAC.

\subsubsection{Solid/solution ratio}

The initial solid/solution ratio (mass GAC (g)/volume solution $(\mathrm{mL})$ ) was varied to assess the role of persulfate reaction $(19.5 \mathrm{~mL}$; $40 \mathrm{~g} \mathrm{~L}^{-1} \mathrm{Na}_{2} \mathrm{~S}_{2} \mathrm{O}_{8} ; 55^{\circ} \mathrm{C}$ ) in the bulk solution (i.e., aqueous solution overlying the saturated GAC in the reactor). The high solid/solution ratio involved $20 \mathrm{~mL}$ of post-sorption solution and $5 \mathrm{~g}$ of GAC (high solid/solution $=0.25 \mathrm{~g} \mathrm{~mL}^{-1}$ ). In the high solid/solution condition, the liquid level was approximately at the surface of the GAC prior to persulfate amendment and MTBE oxidation. In the low solid/solution condition, $50 \mathrm{~mL}$ of post-MTBE solution remained with $5 \mathrm{~g} \mathrm{GAC}$ (low solid/solution $=0.1 \mathrm{~g} \mathrm{~mL}^{-1}$ ). The latter condition exhibited greater bulk solution.

\subsection{4. $\mathrm{pH}$}

The effect of $\mathrm{pH}$ was evaluated by varying the $\mathrm{pH}$ from 4 to 11 . Sodium hydroxide $(\mathrm{NaOH})(0.1,1$, and $5 \mathrm{M})$ was used to adjust the $\mathrm{pH}$. The ambient $\mathrm{pH}$ of GAC in water (initial pH 5.2-5.4) was allowed to vary without $\mathrm{pH}$ modification to assess the extent of $\mathrm{pH}$ change from oxidation.

\subsection{5. $\mathrm{H}_{2} \mathrm{O}_{2} / \mathrm{Na}_{2} \mathrm{~S}_{2} \mathrm{O}_{8}$ binary treatment system}

The $\mathrm{H}_{2} \mathrm{O}_{2}-\mathrm{Na}_{2} \mathrm{~S}_{2} \mathrm{O}_{8}$ binary treatment system was evaluated using two persulfate and $\mathrm{H}_{2} \mathrm{O}_{2}$ concentration combinations, and a constant $\mathrm{Na}_{2} \mathrm{~S}_{2} \mathrm{O}_{8}: \mathrm{H}_{2} \mathrm{O}_{2}$ molar ratio of $1: 31$. The "full-dosage" case involved $40 \mathrm{gL}^{-1} \quad \mathrm{Na}_{2} \mathrm{~S}_{2} \mathrm{O}_{8}(0.5 \mathrm{~mL} / 5 \mathrm{~min})$ with $30 \% \mathrm{H}_{2} \mathrm{O}_{2}$ $(0.29 \mathrm{~mL} / 5 \mathrm{~min})$; the "half-dosage" case involved similar applications but at $20 \mathrm{~g} \mathrm{~L}^{-1} \mathrm{Na}_{2} \mathrm{~S}_{2} \mathrm{O}_{8}$ and $15 \% \mathrm{H}_{2} \mathrm{O}_{2}$.

\subsubsection{Persulfate concentration}

Equal volumes $(19.5 \mathrm{~mL})$ and different concentrations $(10,20$, 40 , and $60 \mathrm{~g} \mathrm{~L}^{-1}$ ) of $\mathrm{Na}_{2} \mathrm{~S}_{2} \mathrm{O}_{8}$ were added to each reactor at the same loading rate $(0.5 \mathrm{~mL} / 5 \mathrm{~min})$ and temperature $\left(55^{\circ} \mathrm{C}\right)$.

\subsection{Sampling}

The MTBE and CF stock solution was sampled (5x), and the post-sorption solution was sampled from each reactor before persulfate was applied. Post-oxidation solution samples $(2 \times)$ were collected $\sim 3-4$ days after oxidation was complete. GAC samples (2x) were collected (after 3-4 days), extracted, and analyzed to quantify post-oxidation contaminant concentrations in the GAC. Methanol $(10 \mathrm{~mL})$ was added to wet GAC $(\sim 3 \mathrm{~g})$ to extract contaminants from GAC. The aqueous samples were analyzed by gas chromatography (GC). The GAC-methanol slurry was sonicated for $3 \mathrm{~min}$, centrifuged, and the methanol extract was analyzed by GC with mass spectroscopy (MS).

\subsection{Analytical}

\subsubsection{Aqueous and solid GAC phase inorganic and organics analyses}

The analysis of GAC for inorganics and organics (MTBE, CF), and analysis of water for organics (MTBE, CF) is described in detail in the Supporting Information section.

\subsection{2. $\mathrm{H}_{2} \mathrm{O}_{2}, \mathrm{Na}_{2} \mathrm{~S}_{2} \mathrm{O}_{8}, \mathrm{pH}$}

Filtered samples $(0.2 \mu \mathrm{m})$ were measured for $\mathrm{H}_{2} \mathrm{O}_{2}(\mathrm{n}=3)$ using a modified peroxytitanic acid colorimetric procedure [20] with a detection limit of $0.1 \mathrm{mg} \mathrm{L}^{-1}$. The $\mathrm{TiSO}_{4}$ reagent was from Pfaltz and Bauer Inc., and the $\mathrm{H}_{2} \mathrm{O}_{2}(30 \%$ wt. solution in water, reagent grade) was from Aldrich. A spectrophotometric method was used for analyzing the persulfate concentration. Filtered reaction solutions $(0.2 \mu \mathrm{m})$ were measured for $\mathrm{Na}_{2} \mathrm{~S}_{2} \mathrm{O}_{8}$. Samples were prepared by placing $0.1 \mathrm{~mL}$ of reaction solution in a $20 \mathrm{~mL}$ vial. Subsequently, $0.9 \mathrm{~mL}$ of DI water, $10 \mathrm{~mL}$ of $2.5 \mathrm{~N} \mathrm{H}_{2} \mathrm{SO}_{4}$ solution, and $0.1 \mathrm{~mL}$ of $0.4 \mathrm{~N}$ ferrous ammonium sulfate solution were added. The contents were mixed and allowed to react ( $40 \mathrm{~min}$ ) after which a $\mathrm{H}_{4} \mathrm{SCN}$ solution $(0.2 \mathrm{~mL} ; 0.6 \mathrm{~N})$ was added, and the absorbance was measured with a spectrophotometer $(\lambda=450 \mathrm{~nm})$ [9]. The slurry $\mathrm{pH}$ was measured using an Orion Sure-Flow ROSS Combination pH probe.

\section{Results and discussion}

\subsection{Temperature}

Greater MTBE transformation and removal from GAC was measured at higher temperatures (Fig. 1$)$. The average $(n=3)$ persulfate anion pseudo-first order reaction rate constant was temperaturedependent: $0.13,0.18,0.46$, and $0.78 \mathrm{~min}^{-1}\left(0.95 \leq r^{2} \leq 0.99\right)$ at 25 , 35,45 , and $55^{\circ} \mathrm{C}$, respectively. The rate constant declined with each successive application of persulfate (Fig. 2, see insert). Although relatively consistent results of persulfate thermolysis have been reported under homogeneous, neutral and acid-catalyzed conditions [21], these results suggest that a reaction mechanism other than thermal activation played a role. For example, background Fe (1020 $\mathrm{mg} \mathrm{kg}^{-1}$ ) [4] and/or functional groups associated with the GAC surfaces may also have caused persulfate reaction. Persulfate reaction and TCE oxidation in GAC under ambient temperature $\left(25^{\circ} \mathrm{C}\right)$ suggests that GAC catalysis of $\mathrm{S}_{2} \mathrm{O}_{8}{ }^{2-}$ is caused by, at least partially, non-thermal means of activation [7]. It has been proposed that oxygen functional groups on the GAC may act as an activator

\begin{tabular}{|c|c|c|c|c|}
\hline \multicolumn{5}{|c|}{$\mathrm{S}_{2} \mathrm{O}_{8}{ }^{2-}$ reaction rate constant $(\mathrm{k})$} \\
\hline $\begin{array}{l}\text { Temp } \\
{ }^{\circ} \mathrm{C}\end{array}$ & $1^{\text {st }}$ oxid & $\begin{array}{c}\left(\min ^{-1}\right) \\
2^{\text {nd }} \text { oxid }\end{array}$ & $3^{\text {rd }}$ oxid & $\begin{array}{l}\text { Avg. } \mathrm{K} \\
\left(\min ^{-1}\right)\end{array}$ \\
\hline 25 & 0.17 & 0.13 & 0.08 & 0.13 \\
\hline 35 & 0.26 & 0.17 & 0.11 & 0.18 \\
\hline 45 & 0.54 & 0.52 & 0.32 & 0.46 \\
\hline 55 & 1.00 & 0.82 & 0.53 & 0.79 \\
\hline
\end{tabular}

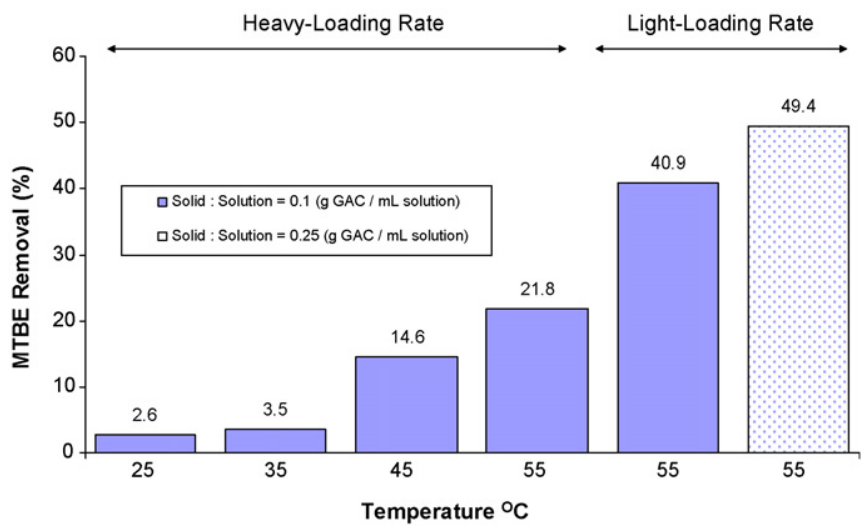

Fig. 1. Effect of temperature, persulfate loading rate, and solid/solution ratio on MTBE removal. Heavy-loading involved 1 application $\left(6.5 \mathrm{~mL} \mathrm{Na}_{2} \mathrm{~S}_{2} \mathrm{O}_{8} ; 40 \mathrm{~g} \mathrm{~L}^{-1}\right)$ per day for 3 sequential days. Light-loading involved 39 applications of $\mathrm{Na}_{2} \mathrm{~S}_{2} \mathrm{O}_{8}$ $(0.5 \mathrm{~mL} / 5 \mathrm{~min})$. The same total volume $(19.5 \mathrm{~mL})$ and concentration $\left(40 \mathrm{~g} \mathrm{~L}^{-1}\right)$ of $\mathrm{Na}_{2} \mathrm{~S}_{2} \mathrm{O}_{8}$ was added in both cases. The low and high solid/solution ratios were 0.1 and $0.25 \mathrm{~g} \mathrm{GAC} \mathrm{mL}^{-1}$ solution, respectively. All tests were run at ambient $\mathrm{pH}$ where $\mathrm{pH}_{\text {INITIAL }} \approx 5.3-5.4$. The inset panel is the persulfate first-order reaction rate constant from three sequential applications. 
(1)

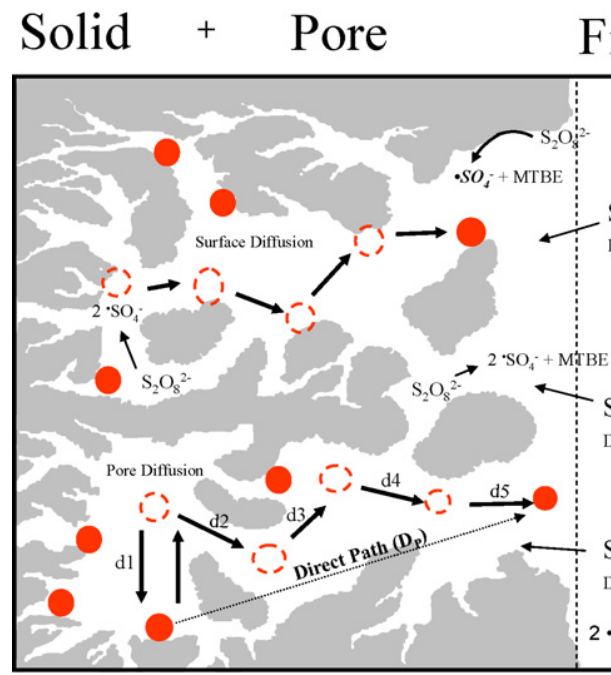

After, De Las Casa et al. (2006)
(3)

Film

(4)

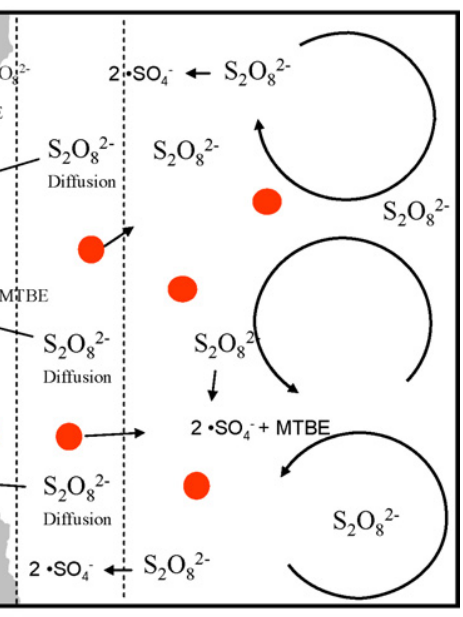

- Contaminant (MTBE)

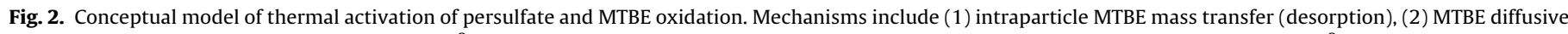

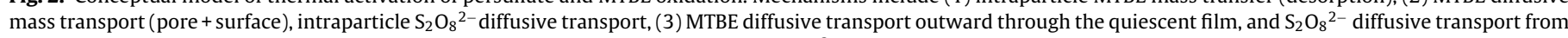

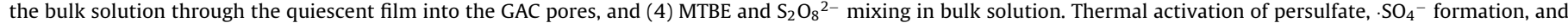
oxidation of MTBE by $\cdot \mathrm{SO}_{4}{ }^{-}$occurs in bulk solution, thin film, and within the pores of the GAC particle.

of the electron-transfer mechanism involving $\mathrm{S}_{2} \mathrm{O}_{8}{ }^{2-}$ reaction and formation of organic and $\mathrm{SO}_{4}{ }^{-}$[7]. The decline in $\mathrm{S}_{2} \mathrm{O}_{8}{ }^{2-}$ in successive applications may also be due to the oxidation and alteration of the functional groups in GAC, and conversion to non-reactive forms similar to results reported in Fenton-driven regeneration of GAC [3,22].

During persulfate oxidation regeneration of spent GAC, contaminant mass transfer and mass transport involves the following steps: (1) desorption from solid to liquid phase, (2) diffusive transport within the pores involving pore and surface diffusion, (3) diffusive transport through a quiescent film surrounding the particle, and (4) advective transport into the bulk solution [23] (Fig. 2). A critical analysis of the temperature-dependence of $\mathrm{S}_{2} \mathrm{O}_{8}{ }^{2-}$ fate and transport in GAC involving numerical modeling of $\mathrm{S}_{2} \mathrm{O}_{8}{ }^{2-}$ diffusive transport and reaction in GAC provides additional insight in MTBE oxidation (refer to Supplemental Information, Section II Numerical Modeling and Results of $\mathrm{S}_{2} \mathrm{O}_{8}{ }^{2-}$ Diffusive Transport and Reaction in GAC). Persulfate is generally more stable than $\mathrm{H}_{2} \mathrm{O}_{2}$, and is likely to persist longer and diffuse further into the GAC particle allowing greater penetration. However, at high temperatures persulfate reaction is fast and limits the diffusive transport and the penetration depth of $\mathrm{S}_{2} \mathrm{O}_{8}{ }^{2-}$. Based on modeling of $\mathrm{S}_{2} \mathrm{O}_{8}{ }^{2-}$ diffusion and reaction in GAC particles at 25 and $55^{\circ} \mathrm{C}, \mathrm{S}_{2} \mathrm{O}_{8}{ }^{2-}$ penetrated the outer-most differential volume at both 25 and $55^{\circ} \mathrm{C}$, however, deeper penetration into the GAC particle was significantly limited. $\mathrm{S}_{2} \mathrm{O}_{8}{ }^{2-}$ concentrations were higher, persisted longer, and penetration was greater at $25^{\circ} \mathrm{C}$ than $55^{\circ} \mathrm{C}$, but overall, concentrations were less than $5 \%$ of the initial concentration in the mid and inner spherical shells. Results suggest that contact between MTBE and . $\mathrm{SO}_{4}{ }^{-}$and/or $\mathrm{S}_{2} \mathrm{O}_{8}{ }^{2-}$ requires MTBE desorption and outward diffusion from the GAC interior to the GAC exterior. The rates of MTBE desorption and diffusion are thermally dependent explaining why greater MTBE oxidation was measured at higher temperature [6].

\subsection{Persulfate loading rate}

The light-loading rate of persulfate $(0.5 \mathrm{~mL} / 5 \mathrm{~min} ; 19.5 \mathrm{~mL}$ total volume; $40 \mathrm{~g} \mathrm{~L}^{-1} \quad \mathrm{Na}_{2} \mathrm{~S}_{2} \mathrm{O}_{8}$ ) enhanced MTBE removal compared with the heavy-loading rate ( 3 applications of $6.5 \mathrm{~mL} ; 19.5 \mathrm{~mL}$ total volume; $40 \mathrm{gL}^{-1} \mathrm{Na}_{2} \mathrm{~S}_{2} \mathrm{O}_{8}$ ), suggesting that $\cdot \mathrm{SO}_{4}{ }^{-}$concentration was not the limiting factor (Fig. 1). The diluted persulfate concentration in the test reactor ranged higher in the heavyloading rate case (5.3-7.1 $\mathrm{g} \mathrm{L}^{-1}$ ) than in the light-loading rate case (0.4-0.66 $\left.\mathrm{g} \mathrm{L}^{-1}\right)$; therefore, the $\cdot \mathrm{SO}_{4}{ }^{-}$production and reaction rates were faster. The first-order reaction rate kinetics (Fig. 1) were used to estimate the time of contact between GAC and $\mathrm{S}_{2} \mathrm{O}_{8}{ }^{2-}$ in the heavy-loading case (18-20 min) and the light-loading case $(>3 \mathrm{~h})$. In chemical regeneration of GAC, the optimal persulfate mass loading represents a balance between the persulfate concentration, rate of application, $\cdot \mathrm{SO}_{4}{ }^{-}$production, and the rate of MTBE desorption, diffusion, and reaction with $\cdot \mathrm{SO}_{4}{ }^{-}$. High persulfate concentration leads to high [. $\left.\mathrm{SO}_{4}{ }^{-}\right]$, fast MTBE oxidation, and low [MTBE] $]_{\text {AQUEOUS. }}$ Because MTBE desorption and diffusion can be limiting factors in GAC systems, heavy persulfate mass loading and high $\cdot \mathrm{SO}_{4}{ }^{-}$concentrations could lead to a rapid decline in [MTBE] $]_{\text {AQUEOUS. Under }}$ this condition, steep concentration gradients would enhance MTBE desorption and diffusion, however, low reaction rates between MTBE and $\cdot \mathrm{SO}_{4}{ }^{-}$attributed to low [MTBE] $]_{\text {AQUEOUS may result in }}$ inefficient MTBE oxidative treatment. Semi-continuous persulfate application (i.e., light-loading) involving frequent applications of small volumes of oxidant over longer time frames resulted in lower $\left[\cdot \mathrm{SO}_{4}{ }^{-}\right]$, higher [MTBE] $]_{\text {AQUEOUS, }}$ longer reaction time between $\cdot \mathrm{SO}_{4}{ }^{-}$ and MTBE, and ultimately, greater oxidation efficiency (i.e., MTBE removed/persulfate reacted).

\subsection{Solid/solution ratio}

The solid/solution ratio is the mass of GAC ( $\mathrm{g}$ ) relative to the volume of solution $(\mathrm{mL})$ in the test reactor. In heterogeneous oxidation systems involving a GAC suspension in solution, thermal activation of persulfate, and the formation and reaction of $\cdot \mathrm{SO}_{4}{ }^{-}$can occur in the aqueous phase found in both the GAC pores and in the bulk solution (Fig. 2). Assuming limited MTBE mass transfer and/or mass transport, and low MTBE concentration in the bulk solution, . $\mathrm{SO}_{4}{ }^{-}$formation and reaction in the bulk solution may occur in the absence of MTBE and represent a source of inefficiency. The higher solid/solution ratio improved MTBE removal under thermalactivation conditions (Fig. 1). MTBE concentrations are limited in 


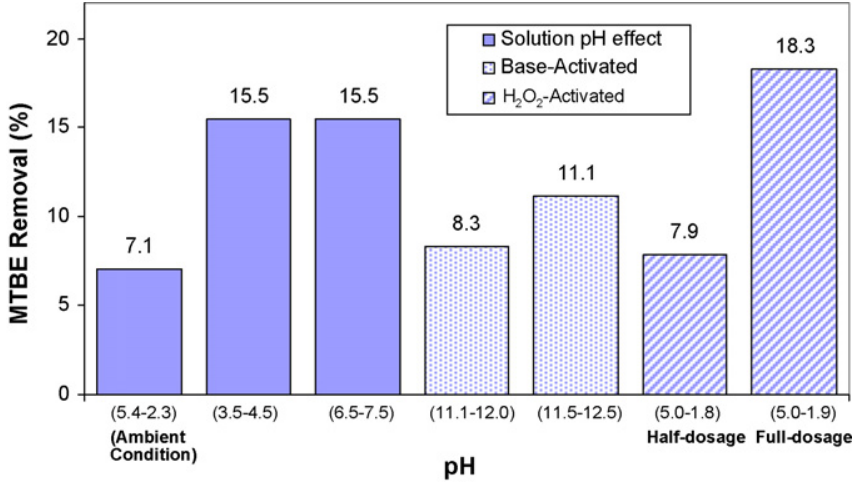

Fig. 3. Effect of solution $\mathrm{pH}$, base-activation ( $\mathrm{pH} 11-12.5$ ), and $\mathrm{H}_{2} \mathrm{O}_{2}$-persulfate binary system on MTBE removal. The ambient (baseline) conditions were; temperature $\left.\left(25^{\circ} \mathrm{C}\right), \mathrm{pH}_{\text {INITIAL }}=5.4, \mathrm{pH}_{\mathrm{FINAL}}=2.3\right)$; light $\mathrm{Na}_{2} \mathrm{~S}_{2} \mathrm{O}_{8}$ loading rate $\left(19.5 \mathrm{~mL}, 40 \mathrm{~g} \mathrm{~L}^{-1}, 0.5 \mathrm{~mL} / 5 \mathrm{~min}\right)$, high solid/solution ratio $\left(0.25 \mathrm{~g} \mathrm{~mL}^{-1}\right) . \mathrm{H}_{2} \mathrm{O}_{2}-$ activation conditions included a constant molar ratio of persulfate and $\mathrm{H}_{2} \mathrm{O}_{2}$ ( $1 \mathrm{mmol} \mathrm{Na} \mathrm{S}_{2} \mathrm{O}_{8}: 31 \mathrm{mmol} \mathrm{H}_{2} \mathrm{O}_{2}$ ) applied at two dosages: half-dosage $=20 \mathrm{~g} \mathrm{~L}^{-1}$ $\mathrm{Na}_{2} \mathrm{~S}_{2} \mathrm{O}_{8}+15 \% \mathrm{H}_{2} \mathrm{O}_{2}$; full dosage $40 \mathrm{gL}^{-1} \mathrm{Na}_{2} \mathrm{~S}_{2} \mathrm{O}_{8}+30 \% \mathrm{H}_{2} \mathrm{O}_{2}$. The $\mathrm{Na}_{2} \mathrm{~S}_{2} \mathrm{O}_{8}$ and $\mathrm{H}_{2} \mathrm{O}_{2}$ were applied at $0.5 \mathrm{~mL} / 5 \mathrm{~min}$ and $0.29 \mathrm{~mL} / 5 \mathrm{~min}$.

the bulk solution (i.e., above the GAC layer) due to both intraparticle diffusive mass transport limitation and rapid MTBE oxidation. Under this condition, reaction of $\mathrm{S}_{2} \mathrm{O}_{8}{ }^{2-}$ and $\cdot \mathrm{SO}_{4}{ }^{-}$in the bulk solution results in inefficient MTBE oxidation. Consequently, under the high solid/solution ratio $\left(0.25 \mathrm{~g} \mathrm{~mL}^{-1}\right)$ condition, limited reaction of $\mathrm{S}_{2} \mathrm{O}_{8}{ }^{2-}$ and $\cdot \mathrm{SO}_{4}{ }^{-}$in the bulk solution resulted in more efficient MTBE oxidation than under the low solid/solution ratio $\left(0.1 \mathrm{~g} \mathrm{~mL}^{-1}\right)$. Therefore, process optimization would include both a high solid/solution ratio and a low loading rate to minimize this potential source of process inefficiency.

\section{4. $\mathrm{pH}$}

Under the ambient conditions where $\mathrm{pH}$ was not controlled, a strongly acidic $\mathrm{pH}(\mathrm{pH}<3)$ resulted within $45 \mathrm{~min}$, eventually

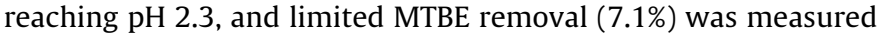
(Fig. 3). Moderate improvement of MTBE removal was measured over ambient conditions when $\mathrm{NaOH}$ was added to maintain the $\mathrm{pH}$ of the GAC slurry in the ranges of $\mathrm{pH} 3.5-4.5$ and 6.5-7.5. Under alkaline-activated conditions, where $\mathrm{NaOH}$ was used to adjust the $\mathrm{pH}$, only minor increases in MTBE removal were measured relative to the ambient case. These results appear to be consistent with non-productive reactions under highly acidic and alkaline conditions ( $\mathrm{R} 4)-(\mathrm{R} 8)$. In other studies, both acidic $(\mathrm{pH}<3)$ and alkaline $(\mathrm{pH}>10)$ homogeneous conditions, acid and hydroxide catalyzed persulfate reactions (R4)-(R8) [24,25 and references therein; 21] resulted in reduced $\cdot \mathrm{SO}_{4}{ }^{-}$formation relative to thermal activation where $2 \mathrm{~mol} \cdot \mathrm{SO}_{4}{ }^{-}$are produced per $\mathrm{mol} \mathrm{S}_{2} \mathrm{O}_{8}{ }^{2-}$ (R2). Another source of inefficiency includes $\cdot \mathrm{SO}_{4}{ }^{-}$scavenging by $\mathrm{H}_{2} \mathrm{O}$ or $\mathrm{OH}^{-}$. Although these scavenging reactions may yield hydroxyl radicals $(. \mathrm{OH})$, this strong non-specific oxidant is also vulnerable to scavenging by various reactants including $\mathrm{SO}_{4}{ }^{2-}$, an abundant specie in persulfate oxidation systems $[9,25]$

$\mathrm{S}_{2} \mathrm{O}_{8}{ }^{2-}+\mathrm{H}^{+} \rightarrow \mathrm{HS}_{2} \mathrm{O}_{8}{ }^{-}$

$\mathrm{HS}_{2} \mathrm{O}_{8}{ }^{-} \rightarrow \mathrm{HSO}_{4}{ }^{-}+\cdot \mathrm{SO}_{4}{ }^{-}$

$\cdot \mathrm{SO}_{4}{ }^{-}+\mathrm{H}_{2} \mathrm{O} \rightarrow \mathrm{H}_{2} \mathrm{SO}_{5}$

$\mathrm{S}_{2} \mathrm{O}_{8}{ }^{2-}+\mathrm{OH}^{-} \rightarrow \mathrm{HSO}_{4}^{-}+\mathrm{SO}_{5}{ }^{2-}$

$\mathrm{SO}_{5}{ }^{2-} \rightarrow \mathrm{SO}_{4}{ }^{2-}+(1 / 2) \mathrm{O}_{2}$

The $\mathrm{pH}$ at point of zero charge $\left(\mathrm{pH}_{\mathrm{PZC}}\right)$ is the $\mathrm{pH}$ at which positive and negative surface charges are equal and the GAC surface has a net charge of zero. The $\mathrm{pH}_{\mathrm{PZC}}$ of the untreated URV GAC is 5.5 [6]. In the alkaline-activated GAC, the solution $\mathrm{pH}$ ( $\mathrm{pH} 11-12.5$ ) was $\gg \mathrm{pH}_{\mathrm{PZC}}$ resulting in a net negative surface charge on the GAC that attracted cations from solution (i.e., $\mathrm{Na}^{+}$). Significant post-oxidation accumulation of Na was measured in the GAC ([Na] $\left.=24 \mathrm{~g} \mathrm{~kg}^{-1}, n=4\right)$, relative to untreated $\mathrm{GAC}\left([\mathrm{Na}]=0.7 \mathrm{~g} \mathrm{~kg}^{-1}\right)$. In this condition, a diffuse layer of $\mathrm{Na}^{+}$, either adsorbed to the GAC surface or weakly associated with the GAC surface, may have contributed to a condition where diffusive transport and reaction of the divalent $\mathrm{S}_{2} \mathrm{O}_{8}{ }^{2-}$ anion in the GAC was limited by electrostatic interaction at the GAC surfaces.

Oxidation of TCE was most effective in the near-neutral $\mathrm{pH}$ range $(\mathrm{pH} 7)$ in an unactivated persulfate treatment system at ambient temperatures $\left(10,20\right.$, and $\left.30^{\circ} \mathrm{C}\right)$ [25]. However, the MTBE reaction rate $\left(1.75 \times 10^{4}-3.05 \times 10^{4} \mathrm{~s}^{-1}\right)$ was inversely proportional with $\mathrm{pH}(2.4-10.9)$ in a thermally activated $\left(40^{\circ} \mathrm{C}\right)$ treatment system [9]. Given the pH-dependency of individual contaminants, in conjunction with different persulfate activation agents, geochemical conditions, and unique combinations of the reactants and experimental conditions, the optimal $\mathrm{pH}$ for contaminant oxidation appears to be site-specific and variable.

\section{5. $\mathrm{H}_{2} \mathrm{O}_{2} / \mathrm{Na}_{2} \mathrm{~S}_{2} \mathrm{O}_{8}$ binary treatment system}

In the $\mathrm{H}_{2} \mathrm{O}_{2}$-activated, half-dosage case $\left(20 \mathrm{~g} \mathrm{~L}^{-1} \mathrm{Na}_{2} \mathrm{~S}_{2} \mathrm{O}_{8} ; 15 \%\right.$ $\mathrm{H}_{2} \mathrm{O}_{2}$ ), no significant improvement was measured over the ambient case (Fig. 3). However, a significant increase was measured in the full-dosage cases $\left(40 \mathrm{~g} \mathrm{~L}^{-1} \mathrm{Na}_{2} \mathrm{~S}_{2} \mathrm{O}_{8} ; 30 \% \mathrm{H}_{2} \mathrm{O}_{2}\right)$. In control reactors containing a homogeneous solution of $\mathrm{H}_{2} \mathrm{O}_{2}(6 \mathrm{mM})$ and $\mathrm{Na}_{2} \mathrm{~S}_{2} \mathrm{O}_{8}(5.6 \mathrm{mM})$, the reaction of $\mathrm{Na}_{2} \mathrm{~S}_{2} \mathrm{O}_{8}\left(k=0.52\right.$ day $\left.{ }^{-1}\right)$ was highly limited relative to $\mathrm{Na}_{2} \mathrm{~S}_{2} \mathrm{O}_{8}$ in GAC (Fig. 2, see inset) suggesting negligible activation by $\mathrm{H}_{2} \mathrm{O}_{2}$. Under these experimental conditions, other mechanisms in MTBE transformation appeared to play a role including, (i) Fenton-driven oxidation of MTBE, (ii) Fenton-driven formation of ferrous iron intermediate, a known activator of persulfate, and/or (iii) thermal activation of persulfate resulting from $\mathrm{H}_{2} \mathrm{O}_{2}$ exothermic reactions.

\subsection{Persulfate concentration (persulfate mass loading)}

MTBE oxidation and removal from GAC increased with the $\mathrm{Na}_{2} \mathrm{~S}_{2} \mathrm{O}_{8}$ dosage (Fig. 4). However, the oxidation efficiency (i.e., MTBE removed/persulfate reacted) decreased with increasing concentration. This is attributed to slow intraparticle MTBE desorption and diffusion from the GAC, in conjunction with $\mathrm{S}_{2} \mathrm{O}_{8}{ }^{2-}$ and $\cdot \mathrm{SO}_{4}{ }^{-}$ reactions in the bulk solution involving either low or negligible concentrations of MTBE.

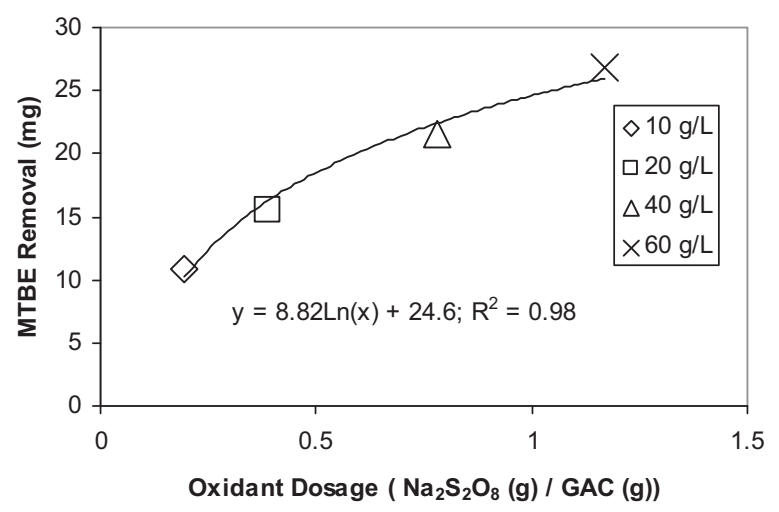

Fig. 4. Effect of $\mathrm{Na}_{2} \mathrm{~S}_{2} \mathrm{O}_{8}$ dosage $\left(10,20,40\right.$, and $60 \mathrm{~g} \mathrm{~L}^{-1}$ stock solution; $\left.19.5 \mathrm{~mL}\right)$ on MTBE removal $\left(55^{\circ} \mathrm{C}\right.$; light-loading rate $(0.5 \mathrm{~mL} / 5 \mathrm{~min})$; high solid/solution ratio $=0.25 \mathrm{~g} \mathrm{~mL}^{-1}$ ). 


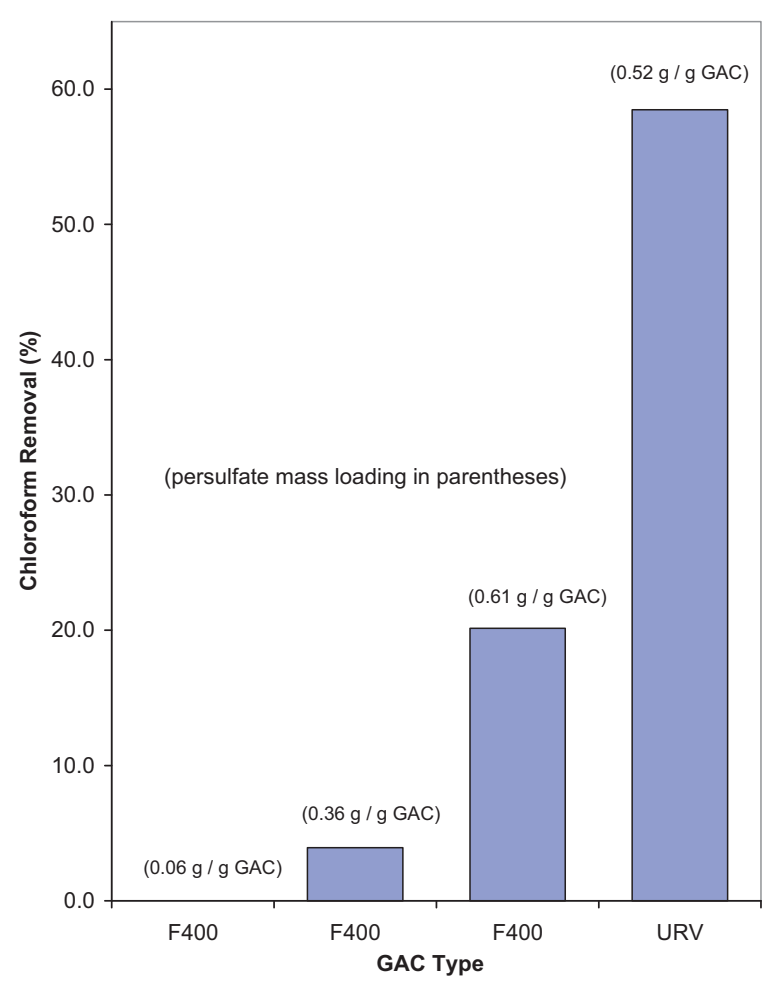

Fig. 5. Effect of GAC type and $\mathrm{Na}_{2} \mathrm{~S}_{2} \mathrm{O}_{8}$ concentration (persulfate mass loading) on MTBE removal. Two GAC types include Calgon Carbon Corporation F400, and URV. Three initial concentrations of $\mathrm{Na}_{2} \mathrm{~S}_{2} \mathrm{O}_{8}\left(50,300\right.$, and $\left.500 \mathrm{~g} \mathrm{~L}^{-1}\right)$ were applied to the GAC $(\approx 1 \mathrm{~g})$ involving the same volume $(19.5 \mathrm{~mL})$ and oxidant application rate $(0.1 \mathrm{~mL} / 10 \mathrm{~min})$ resulting in different $\mathrm{Na}_{2} \mathrm{~S}_{2} \mathrm{O}_{8}$ mass loadings $(0.06-0.61 \mathrm{~g}$ persulfate $/ \mathrm{g} \mathrm{GAC})\left(55^{\circ} \mathrm{C}\right.$; high solid/solution ratio $\left.=0.25 \mathrm{~g} \mathrm{~mL}^{-1}\right)$.

\subsection{Oxidation regeneration of chloroform-spent GAC}

The average $\mathrm{CF}$ concentration was $0.34 \mathrm{mg} \mathrm{CF} / \mathrm{g}$ GAC $(n=15,95 \%$ confidence interval $0.32-0.36 \mathrm{mg}$ (F/g GAC) in the F400 GAC, and $0.40 \mathrm{mg} \mathrm{CF} / \mathrm{g} \mathrm{GAC}(n=5,95 \%$ confidence interval $0.37-0.43 \mathrm{mg} \mathrm{CF} / \mathrm{g}$ GAC) in the URV GAC. CF loss due to non-oxidative fate mechanisms was negligible in control reactors $(n=5)$ involving two-way, mini-inert valve cap vials. Chloroform removal was limited in the F400 GAC despite aggressive persulfate mass loading (Fig. 5). Significantly greater CF removal was measured in the URV GAC than in the F400 GAC.

URV GAC has greater surface area, pore volume and fraction of meso + macropore volume than the F400 (Table 1). Greater surface area would contribute to faster mass transfer of CF from GAC surfaces. Greater pore volume and larger pores would contribute to fewer chemical interactions between the aqueous solute(s) and GAC surfaces allowing unimpeded intraparticle diffusion transport

Table 1

Physical and chemical characteristics of granular activated carbon. ${ }^{\mathrm{a}}$

\begin{tabular}{lll}
\hline Parameter & F400 $(n=3)$ & URV $(n=3)$ \\
\hline BET surface area $\left(\mathrm{m}^{2} \mathrm{~g}^{-1}\right)$ & $990(940-1030)$ & $1290(1260-1330)$ \\
& & $(n=3)$ \\
Mean pore volume $\left(\mathrm{mLg}^{-1}\right)$ & $0.38(0.37-0.39)$ & 0.386 \\
Micro & $0.13(0.12-0.14)$ & 0.257 \\
Meso + macro & $0.505(0.50-0.51)$ & $0.64(0.61-0.67)$ \\
Total & & \\
& & $(n=2)$ \\
Surface functionality (meq/100 g) & $14.5(12.1-17.0)$ & 48.3 \\
Acid surface oxides & $39.6(39.0-40.1)$ & 30.8 \\
Basic surface oxides & & \\
\hline
\end{tabular}

a Values in parentheses are the $95 \%$ confidence intervals. of $\mathrm{CF}$ and $\mathrm{S}_{2} \mathrm{O}_{8}{ }^{2-}$. Functional groups found at the edges and surfaces of graphene planes in GAC can be characterized based on oxygen content. Basic surface oxide (BSO) functional groups have low oxygen content, exhibit anion exchange capacity, are highly reactive with $\mathrm{H}_{2} \mathrm{O}_{2}$, and are non-productive (i.e., do not yield. $\mathrm{OH}$ in Fenton systems) [26]. Assuming a similar mechanism where persulfate is consumed and $\mathrm{SO}_{4}{ }^{-}$are not produced, BSOs may also be a limiting factor in persulfate-driven regeneration of GAC. In contrast, acidic surface oxide (ASO) functional groups have high oxygen content, exhibit a cation exchange capacity, and are non-reactive with $\mathrm{H}_{2} \mathrm{O}_{2}$. F400 had a higher BSO content than URV (Table 1); this may have contributed to process inefficiency. It is noted that oxidative and/or acidic treatment of GAC alters BSOs to form ASOs. Consequently, modification of the GAC surfaces during oxidative treatment would lower the BSO content, reducing and/or eliminating this source of process inefficiency [22]. Evidence of this mechanism is suggested by the decline in persulfate reaction rates resulting from successive applications of persulfate (Fig. 2, see inset).

The CF-spent F400 GAC may have contained residual NOM that was not fully removed in the upstream treatment units at the water treatment plant designed to remove NOM (i.e., chlorination, alum precipitation, primary GAC treatment, and chlorination). Consequently, the roles of GAC type and NOM on CF removal under these two conditions cannot be fully differentiated. However, results are consistent with a screening study conducted in our laboratory involving 30 commercially available GAC types where contaminant removal measured in F400 relative to other GAC types, including URV was highly limited (data not included). Overall, results suggest that the GAC properties strongly influence the feasibility of chemical regeneration.

\subsection{Further improvements}

The highest MTBE removal (61.0\%) was achieved using thermal activation $\left(55^{\circ} \mathrm{C}\right)$, ambient $\mathrm{pH}\left(\mathrm{pH}_{\text {INITIAL }} \sim 5.4, \mathrm{pH}_{\text {FINAL }}<2.0\right)$, light-loading rate of $\mathrm{Na}_{2} \mathrm{~S}_{2} \mathrm{O}_{8}(0.5 \mathrm{~mL} / 5 \mathrm{~min})$, high persulfate concentration $\left(60 \mathrm{~g} \mathrm{~L}^{-1}\right)$, and high solid/solution ratio $\left(0.25 \mathrm{~g} \mathrm{GAC} \mathrm{mL}^{-1}\right.$ solution). Further improvement in treatment efficiency may possibly be achieved by (1) maintaining the $\mathrm{pH}$ in the acidic to neutral range (i.e., $\mathrm{pH} 3-7$ ), (2) more frequent, lower oxidant loading rate (i.e., application of smaller volumes of persulfate solution over a longer period of time), (3) periodically wasting solution from the GAC slurry to maintain a high solid/solution ratio, and (4) selection of GAC with appropriate chemical and physical characteristics. Additionally, thermal-activation at higher temperatures $\left(>55^{\circ} \mathrm{C}\right)$ may increase MTBE desorption and diffusive transport and enhance oxidative treatment.

\section{Conclusions}

Thermal-activation of persulfate was effective and resulted in greater MTBE removal than either alkaline-activation or binary systems involving $\mathrm{H}_{2} \mathrm{O}_{2}$ and persulfate. Greater MTBE oxidation was measured at a lower $\mathrm{pH}$ range $(\mathrm{pH}$ 3.5-7.5) than under alkalineactivation conditions ( $\mathrm{pH} 11-12.5)$. Limited MTBE removal was measured involving a binary mixture of $\mathrm{H}_{2} \mathrm{O}_{2}$ and persulfate under half-dosage conditions $\left(20 \mathrm{~g} \mathrm{~L}^{-1} \mathrm{Na}_{2} \mathrm{~S}_{2} \mathrm{O}_{8}: 15 \% \mathrm{H}_{2} \mathrm{O}_{2}\right)$. In the fulldosage case $\left(40 \mathrm{~g} \mathrm{~L}^{-1} \mathrm{Na}_{2} \mathrm{~S}_{2} \mathrm{O}_{8}: 30 \% \mathrm{H}_{2} \mathrm{O}_{2}\right)$, significant improvement in MTBE removal was measured. In the $\mathrm{H}_{2} \mathrm{O}_{2}$-persulfate binary treatment system, $\mathrm{H}_{2} \mathrm{O}_{2}$ may have played multiple roles including: (i) Fenton-driven oxidation of MTBE resulting from the reaction of $\mathrm{H}_{2} \mathrm{O}_{2}$ with background $\mathrm{Fe}$ in GAC and formation of . $\mathrm{OH}$, (ii) Fentondriven formation of ferrous iron intermediate, a known activator of persulfate, and/or (iii) exothermic $\mathrm{H}_{2} \mathrm{O}_{2}$ reactions followed by an increase in temperature and thermal-activation of persulfate. 
The low persulfate loading rate involved more frequent and lower volume applications of $\mathrm{Na}_{2} \mathrm{~S}_{2} \mathrm{O}_{8}$ (i.e., "light-loading rate") and was more efficient in MTBE removal than "heavy-loading rate" which involved less frequent applications and larger volumes of $\mathrm{Na}_{2} \mathrm{~S}_{2} \mathrm{O}_{8}$. Greater MTBE removal was measured at a higher solid/solution ratio (i.e., $0.25 \mathrm{~g} \mathrm{~mL}^{-1}$ versus $0.1 \mathrm{~g} \mathrm{~mL}^{-1}$ ). Results suggest that $\mathrm{S}_{2} \mathrm{O}_{8}{ }^{2-}$ and $\cdot \mathrm{SO}_{4}{ }^{-}$reaction in the bulk solution when MTBE concentrations are limited or absent, represents a source of treatment inefficiency. MTBE oxidation and removal from GAC increased with $\mathrm{Na}_{2} \mathrm{~S}_{2} \mathrm{O}_{8}$ concentration. However, oxidation efficiency (i.e., MTBE removed/persulfate reacted) decreased with increasing persulfate concentration. Collectively, these results are consistent with a conceptual model in which the intraparticle MTBE diffusion rate is the rate-limiting factor in chemical regeneration of GAC. Chloroform oxidation was more effective in the URV than the F400 GAC.

\section{Acknowledgments}

The authors acknowledge Caleb Wingo (East Central University, Ada, OK) for laboratory assistance; and M. Blankenship, Steve Markham, and T. Pardue (Shaw Environmental \& Infrastructure, Inc., Ada, OK) for analytical support, and Larry Parrish (International Paper Inc., Texarkana, TX) for supplying chloroform-spent F400 GAC.

\section{Appendix A. Supplementary data}

Supplementary data associated with this article can be found, in the online version, at doi:10.1016/j.jhazmat.2011.06.070.

\section{References}

[1] P.P. Leahy, T.H. Thompson, US Geological survey national water quality assessment program, USGS Open-File Report 94-70, USGS, Reston, VA, 1994

[2] USEPA, MTBE in Drinking Water, http://www.epa.gov/safewater/contaminants/ unregulated/mtbe.html, 2010.

[3] S.G. Huling, P.K. Jones, W.P. Ela, R.G. Arnold, Fenton-driven chemical regeneration of MTBE-spent GAC, Water Res. 39 (2005) 2145-2153.

[4] S.G. Huling, K.P. Jones, T. Lee, Iron optimization for Fenton-driven oxidation of MTBE-spent granular activated carbon, Environ. Sci. Technol. 41 (2007) 4090-4096.

[5] S.G. Huling, E. Kan, C. Wingo, Fenton-driven regeneration of MTBE-spent granular activated carbon-effects of particle size and iron amendment procedures, J. Appl. Catal. B: Environ. 89 (2009) 651-657.

[6] E. Kan, S.G. Huling, Effects of temperature and acidic pre-treatment on Fenton-driven oxidation of MTBE-spent granular activated carbon, Environ. Sci. Technol. 43 (2009) 1493-1499.
[7] C. Liang, Y. Lin, W. Shin, Persulfate regeneration of trichloroethylene spent activated carbon, J. Hazard. Mater. 168 (2009) 187-192.

[8] R.E. Huie, C.L. Clifton, P. Neta, Electron transfer reaction rates and equilibria of the carbonate and sulfate radical anions, Radiat. Phys. Chem. 38 (1991) 477-481.

[9] K.C. Huang, R.A. Couttenye, G.E. Hoag, Kinetics of heat-assisted persulfate oxidation of methyl tert-butyl ether, Chemosphere 49 (2002) 413-420.

[10] K.C. Huang, Z. Zhao, G.E. Hoag, A. Dahmani, P.A. Block, Degradation of volatile organic compounds with thermally activated persulfate oxidation, Chemosphere 61 (2005) 551-560.

[11] C. Liang, C.J. Bruell, Thermally activated persulfate oxidation of trichloroethylene: experimental investigation of reaction orders, Ind. Eng. Chem. Res. 47 (2008) 2912-2918.

[12] R.H. Waldemer, P.G. Tratnyek, R.L. Johnson, J.T. Nurmi, Oxidation of chlorinated ethenes by heat-activated persulfate: kinetics and products, Environ. Sci. Technol. 41 (2007) 1010-1015.

[13] G.P. Anipsitakis, D.D. Dionysiou, Radical generation by the interaction of transition metals with common oxidants, Environ. Sci. Technol. 38 (2004) 3705-3712.

[14] C. Liang, C.J. Bruell, M.C. Marley, K.L. Sperry, Persulfate oxidation for in situ remediation of TCE. I. Activated by ferrous ion with and without a persulfatethiosulfate redox couple, Chemosphere 55 (2004) 1213-1223.

[15] M.L. Crimi, J. Taylor, Experimental evaluation of catalyzed hydrogen peroxide and sodium persulfate for destruction of BTEX contaminants, Soil Sediment. Contam. 16 (2007) 29-45.

[16] P.A. Block, R.A. Brown, D. Robinson, Novel activation technologies for sodium persulfate in situ chemical oxidation, in: Proceedings of the 4th International Conference on Remediation of Chlorinated and Recalcitrant Compounds, Monterey, CA; Battelle Press, Columbus, OH, May, 2004, ISBN: 1-57477-145-0, Paper 2A-05.

[17] D.K. Root, E.M. Lay, P.A. Block, W.G. Cutler, Investigation of chlorinated methanes treatability using activated sodium persulfate, in: Proceedings of the 1st International Conference on Environmental Science and Technology, New Orleans, LA, 23-26 January 2005, 2005.

[18] FMC, Procedure for Activating Klozur ${ }^{\circledR}$ Persulfate with a $25 \%$ Sodium Hydroxide Solution, http://www.envsolutions.fmc.com/Klozur/KlozurActivators tabid/3566/Default.aspx, 2009.

[19] R. Hayden, Calgon Carbon Corporation, Personal Communication, Pittsburgh, PA, 1998.

[20] D.F. Boltz, J.A. Howell (Eds.), Colorimetric Determination of Non-metals, WileyInterscience Publication, John Wiley and Sons, New York, 1978.

[21] R.L. Johnson, P.G. Tratnyek, R.B. Johnson, Persulfate persistence under thermal activation conditions, Environ. Sci. Technol. 42 (2008) 9350-9356.

[22] P.K. Jones, Impact of Surface Chemistry Modification on Fenton Regeneration of Activated Carbon. Masters' Thesis, University of Oklahoma, Department of Environmental Science and Engineering, 2007.

[23] C. De Las Casas, K. Bishop, L. Bercik, M. Johnson, M. Potzler, W. Ela, A.E. Sáez, S.G. Huling, R.G. Arnold, In-place regeneration of GAC using Fenton's reagents. In innovative approaches for the remediation of subsurface-contaminated hazardous waste sites: bridging flask and field scales, in: C. Clark, A. Lindner (Eds.), ACS Symposium Series, 940, 2006, pp. 43-65.

[24] I.M. Kolthoff, I.K. Miller, The chemistry of persulfate. I. The kinetics and mechanism of the decomposition of the persulfate ion in aqueous medium, J. Am. Chem. Soc. 73 (1951) 3055-3059.

[25] C. Liang, Z. Wang, C.J. Bruell, Influence of $\mathrm{pH}$ on persulfate oxidation of TCE at ambient temperatures, Chemosphere 66 (2007) 106-113.

[26] K. Kinoshita, Carbon: Electrochemical and Physicochemical Properties, WileyInterscience Publication, John Wiley and Sons, New York, NY, 1988. 